\title{
Exploring the Relationships of Experiential Value, Destination Image and Destination Loyalty: A Case of Macau Food Festival
}

\author{
Yitong Deng1, Ying Tang2* \\ ${ }^{1}$ Faculty of Hospitality and Tourism Management, Macau University of Science and Technology, Macau, China \\ ${ }^{2}$ School of Business, Lingnan Normal University, Zhanjiang, China \\ Email: 417535165@qq.com, ^tangying9590@163.com
}

How to cite this paper: Deng, Y. T., \& Tang, Y. (2020). Exploring the Relationships of Experiential Value, Destination Image and Destination Loyalty: A Case of Macau Food Festival. Journal of Service Science and Management, 13, 841-854.

https://doi.org/10.4236/jssm.2020.136052

Received: November 21, 2020

Accepted: December 28, 2020

Published: December 31, 2020

Copyright $\odot 2020$ by author(s) and Scientific Research Publishing Inc. This work is licensed under the Creative Commons Attribution International License (CC BY 4.0).

http://creativecommons.org/licenses/by/4.0/

\begin{abstract}
Festival has been taken advantaged by destination marketing organization (DMO) for promoting their destination. This paper focuses on the role of food festival in the development of tourism destination, and explores the relationships among the experiential value of food festival, destination image and destination loyalty. Research data were collected at the eighteenth Macau food festival and the relationships were tested by Structural Equation Modeling (SEM). Experiential value scale (EVS) (Mathwick, Malhotra, \& Rigdon, 2001) was adopted in this study. It was found that the experiential value of tourists in the food festival positively influence destination image and destination loyalty. This study suggests that food festival organizers should pay attention to and create the experiential value (playfulness, aesthetics, excellent service and customer return on investment) for tourists in order to effectively promote destination image and strengthen destination loyalty.
\end{abstract}

\section{Keywords}

Experiential Value, Destination Image, Destination Loyalty, Food Festival

\section{Introduction}

Tourists usually spend about $40 \%$ of their budget on food during their travels (Boyne, Williams, \& Hall, 2002). Food provides authentic experience to tourists (Sims, 2009), which is regarded as a powerful driving force for sustainable tourism development and an important part of cultural tourism (Hall \& Mitchell, 2001). Horng and Tsai (2012) believe that enjoying delicious food and pursuing food-related cultural experience are critical motivations of modern tourists. As an essential part of the travel process, food can also be used as an attraction (Stone, 
Soulard, Migacz, \& Wolf, 2018). Especially for certain destinations, food plays a critical role in their image building and is a key factor in attracting tourists to their destinations (Horng \& Tsai, 2012; Okumus, Kock, Scantlebury, \& Okumus, 2013).

As a special tourism product, festival can provide tourists with a good opportunity to experience the local culture and lifestyle of destinations in a very limited time (Deng \& Li, 2014). Therefore, festivals are used as a means of destination branding (Chalip \& Costa, 2005). With the growing interest in food tourism, many food festivals have emerged and become interesting forms of entertainment and tourist attractions (Lee \& Arcodia, 2011). The food festival mainly highlights local cuisine and features food as the theme and characteristics. Its contribution to destination is not only reflected in its economic benefits (Rand, Heath, \& Alberts, 2003), but also in the value-added of existing tourism products (Quan \& Wang, 2004). To sum up, food festival is a tourism activity that combines the characteristics of food and festival while plays an important role in the destination image building.

Consumers are no longer satisfied with simple barter; instead pursue personalized experience to obtain a sense of participation (LaSalle \& Briton, 2003). At the same time, value is considered to be the most important concern of consumers (Holbrook, 1986), and also a major factor affecting the overall tourism perception (Tsai \& Wang, 2017). Therefore, how to create better experiential value and bring greater satisfaction to tourists has become the focuses of many tourism operations and the ultimate goals of tourism marketing (Chi \& Qu, 2008; Parasuraman, Zeithaml, \& Berry, 1998).

Previous studies show the importance of food festivals to destination development, however, little research has been found from visitor experience perspective. This study aimed to examine the relationships between food festival experiential value, destination image and destination loyalty.

\section{Literature Review}

\subsection{Experiential Value}

The study of experiential value is different from experiential research, which focuses more on value creation (Sørensen \& Jensen, 2015). Experiential value can provide consumers with both internal and external benefits (Babin, Darden, \& Griffin, 1994). Holbrook (1994) systematically divides experiential value into three kinds of combinatorial dimensions, namely, the external value of product and service to intrinsic value, the self-oriented value of tourists to others, and the active value to passive value in the process of tourism experience. Based on these three categories, Mathwick, Malhotra and Rigdon (2001) further developed experiential value scale (EVS) to measure the experiential value of consumers. The EVS includes playfulness and aesthetics which exist within the experience, and excellent service, consumer return on investment (CROI) from external.

In EVS, Mathwick et al. (2001) define playfulness as the enjoyment of indulging in pleasure activities in order to get rid of the pressures of daily life. Playfulness experience can provide tourists with physical and mental rest, which can be 
summarized as the most basic level of tourism experience (Pine \& Gilmore, 1998). Tsai and Wang (2017) found that playfulness during meals can improve the experience of eating, which leads to the overall perception of restaurants.

Aesthetics is interpreted as visual perception generated in the process of tourism, which is reflected in the evaluation of aesthetic elements (Mathwick et al., 2001). In Ryu and Han's (2011) empirical study of restaurant experience, aesthetics of restaurants and food have been proved to be able to enhance consumer satisfaction and loyalty. In the experience research of B \& B, aesthetics has also been confirmed to be one of the main experiences that visitors receive during the experience (Deng \& Lee, 2019).

Norris (1941) believes that service should be paid more attention than the product itself during an experience. According to Zeithaml (1988), the value of service excellence comes from service providers, and that the services provided are recognized through professional and task-oriented performance. In Jang and Namkung's (2009) study, the quality of service is more likely to arouse consumers' emotional reactions than food quality.

Return on investment is understood to be an effective return on finance, time, behavior and psychological resources (Grewal, Monroe, \& Krishnan, 1996). In traditional interpretation, the value that consumers care about is the compromise between quality and price (Dodds \& Monroe, 1985). For event participation, price sensitivity is an effective factor in the willingness of tourists to participate as they compare pleasure with cost (Masiero \& Nicolau, 2012).

\subsection{Destination Image}

Tourists have a perception of the overall image of the destination, which is called destination image (Fakeye \& Cronmpton, 1991). The destination image is considered to be a tourism experience combining different scenic spots, material resources, natural environment, cultural heritage, activities and other resources with traditional culture (Kolb, 2006). Integrating with tourists' faith, values and impressions of destination, destination image play a critical role in tourism marketing (Crompton, 1979). Bigne, Snchez and Snchez (2001) also emphasized the importance of destination image, which was a key variable for the segmentation and analysis of individual motivation and actual behavior.

In the study of destination image, local food and culture are believed to increase the value of the destination, and local cuisine can effectively strengthen tourists' overall image (Telfer \& Wall, 1996; du Rand, Heath, \& Alberts, 2003; Hammitt, Backlund, \& Bixler, 2006). In the study of the relationship between destination image and food, clearly indicated that the pleasure provided by food experience is the key variable to enhance the distinctiveness between destinations and their competitors (Ignatov \& Smith, 2006).

Through empirical studies on the World Cup, Olympic Games and some other mega activities, many scholars have found that festival activities can have positive or negative effects on destination image because they can meet a series of value propositions of tourism needs (Funk, Mahony, Nakazawa, \& Hirakawa, 
2001; Kim \& Chalip, 2004; Kim, Kang, \& Kim, 2014). Meanwhile, gastronomic activities have been proven by many studies to be part of the tourism strategy by creating and improving destination image (Kivela, 2006; Fox, 2007). Hence, food festivals are believed to help shape destination brand and effectively enhance destination image (Lee \& Arcodia, 2011).

\subsection{Destination Loyalty}

Loyalty is a key issue in destination management because tourists with high loyalty are more likely to extend their stay at destinations and increase their expenditure during the trip (Oppermann, 2000). At the same time, destination loyalty is more regarded as an extension of customer loyalty (Zhang, Fu, Cai, \& $\mathrm{Lu}, 2014)$. Destination loyalty is regarded as the success of destination marketing (Chi \& Qu, 2008).

Destination loyalty can be interpreted as tourists' obvious preference for destination and their commitment to participating in activities. It can be divided into attitude and behavior (Backman \& Crompton, 1991; Jang \& Feng, 2007; Lee, Lee, Lee, \& Babin, 2008). The behavioral aspect is mainly manifested in the tendency of tourists to purchase or revisit. Therefore, the willingness to revisit has been proved in many studies as a representative feature of tourists' loyalty ( $\mathrm{Qu}$, Kim, \& Im, 2011). The loyalty of tourists is reflected in the overall attitude of tourists to the destination, whether they hold a positive attitude and have the willingness to recommend to the potential visitors. Recommendation intention is also understood as positive word-of-mouth, which is regarded as an important source of information affecting consumers' decision-making (Oppermann, 2000; Yvette \& Turner, 2002).

Food experience has an impact on destination image (Hsu \& Scott, 2020). Experiential value is considered to be a key factor to determine customer loyalty (Zeithaml, 1988). In the previous study of destination image and loyalty, the relationship between them has been confirmed many times (Ragb, Mahrous, \& Ghoneim, 2020; Zhang et al., 2014). However, there is no study about the relationship between experiential value, destination image and loyalty in festivals. Therefore, this study proposes the following hypothesis (proposed model is shown in Figure 1):

H1 Experiential value in food festival positively influences destination image.

H2 Experiential value in food festival positively influences destination loyalty.

H3 Destination image positively influences destination loyalty.

\section{Method}

In this study, Macau, China was selected as the sample collection site. As a city transforming to a diversified industrial structure, event tourism is encouraged and supported by Macau government (Xu, Wong, \& Tan, 2016). Especially as a base for communication and cultural exchange between the East and the West, Macau's diversified cuisine has always been a tourist attraction. 


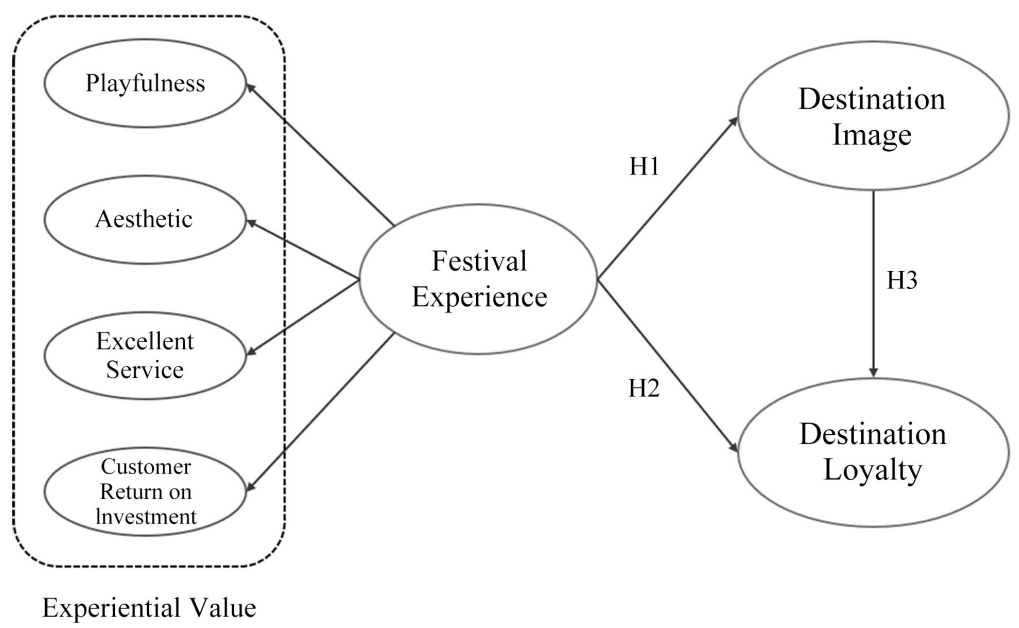

Figure1. Proposed model.

The pilot test was carried out among 50 college students who visited Macau. And this is the prediction test.

The formal questionnaire includes 22 items, adopting a 5-point Likert scale ranging from 5 (strongly agree) to 1 (strongly disagree).

Data samples were collected from the 20th Macau Food Festival held from November $13^{\text {th }}$ to $29^{\text {th }}, 2020$. A total of 400 questionnaires were distributed and 374 valid questionnaires were retained, with an effective rate of $93.5 \%$.

\section{Results}

As shown in Table 1, 59.1\% of respondents were female, $40.9 \%$ were male. Among the respondents, $64.7 \%$ were aged 18 - 29, 22\% were aged $30-39,10.2 \%$ were aged $40-49$, and $3.2 \%$ were older than 50 . More than half of the respondents visiting Macao for the first time accounted for $61.5 \% .54 .0 \%$ of the respondents attended the food festival with their families and $24.8 \%$ went with their friends. Generally speaking, the general characteristics of the respondents to the food festival are that young and middle-aged female tourists travel to Macao for the first time with their families.

In this study, Cronbach's alphas was used to measure the reliability of data samples. The result of 18 items is 0.932 , which is well above the reference value of 0.7 (Devellis, 2003). AMOS 24.0 was used for confirmatory factor analysis of six variables, as shown in Figure 2.

The fitting index of the model is up to the standard, which indicates that the fitting degree between the sample and CFA model is good. According to factor loading, combination reliability (CR) and average precipitation variance (AVE) are calculated, both of which reach the reference values of 0.7 and 0.5 as shown in Table 2 shows (Hair, Black, Babin, \& Anderson, 2014). Fornell and Larcker (1981) proposed that when the AVE of each variable in CFA is lower than the square of the correlation coefficients among variables, there is a good discriminent effect between variables. As shown in Table 3, the AVE values of 
CFA variables in this study are lower than the correlation coefficients among variables, and the six variables used in this study have very good discriminatory validity. Through CFA analysis, the six variables of data samples have good convergent validity and discriminative validity. The AVE of the six variables is: $0.637,0.729,0.712,0.824,0.651,0.727$.

In the model fitting of CFA, the indices reach reference value as show in $\mathrm{Ta}$ ble $4\left(\mathrm{x}^{2} / \mathrm{df}=2.873, \mathrm{GFI}=0.903, \mathrm{RMSEA}=0.71, \mathrm{CFI}=0.953, \mathrm{TLI}=0.940, \mathrm{NFI}\right.$ $=0.930, \mathrm{PGFI}=0.634, \mathrm{PNFI}=0.729, \mathrm{PCFI}=0.747)$. Path analysis was used to verify the hypothesis, as show in Figure 3 . The chi-square test and the model fitting index are shown in Table $4\left(\mathrm{x}^{2} / \mathrm{df}=2.884, \mathrm{GFI}=0.897, \mathrm{RMSEA}=0.71, \mathrm{CFI}\right.$ $=0.949, \mathrm{TLI}=0.939, \mathrm{NFI}=0.925, \mathrm{PGFI}=0.672, \mathrm{PNFI}=0.774, \mathrm{PCFI}=0.794)$. The results show that the SEM can reasonably explain the hypothetical relationship proposed in this study.

As predicted, experiential value in food festival positively influences destination image $(\mathrm{H} 1, \beta=0.469, p<0.001)$. Experiential value in food festival positively influences destination loyalty $(\mathrm{H} 2, \beta=0.253, p<0.01)$. Destination image positively influences destination loyalty $(\mathrm{H} 3, \beta=0.323, p<0.001)$. Therefore, according to the results of SEM (shown in Table 5), three hypotheses proposed in this paper have been verified.

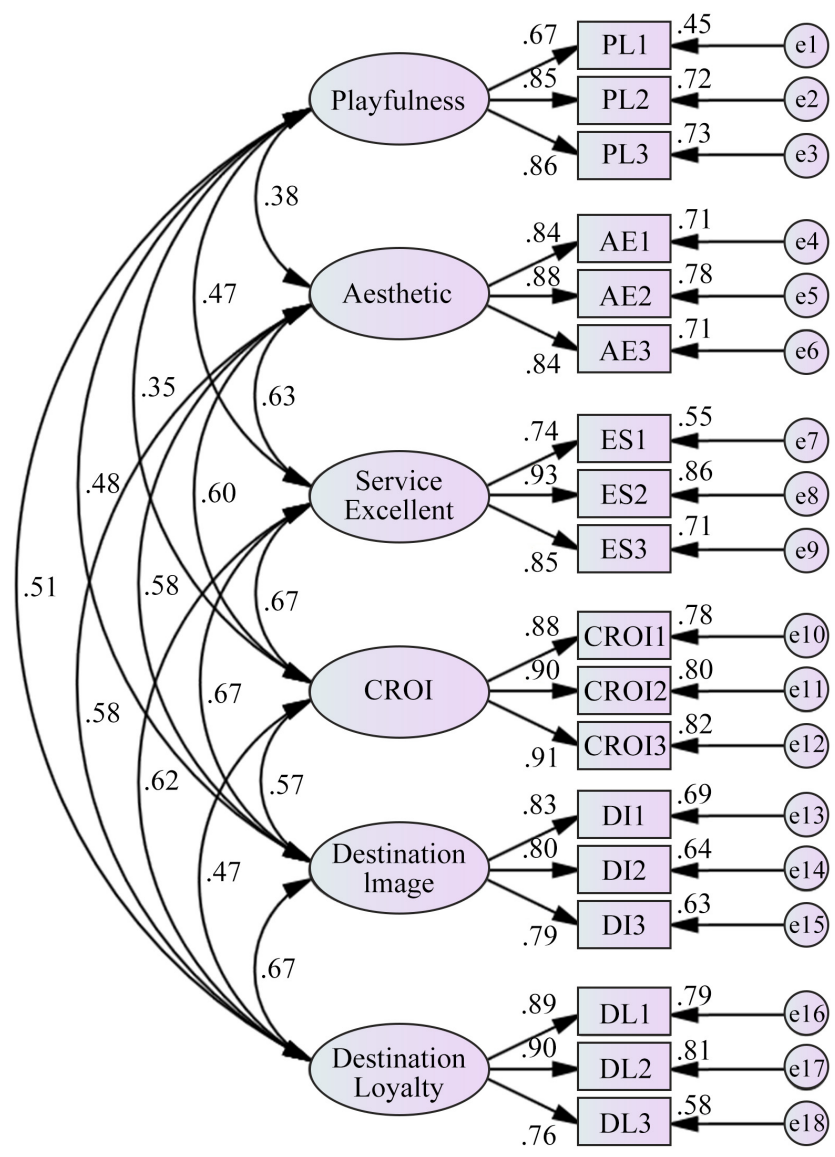

Figure 2. Results of CFA. 


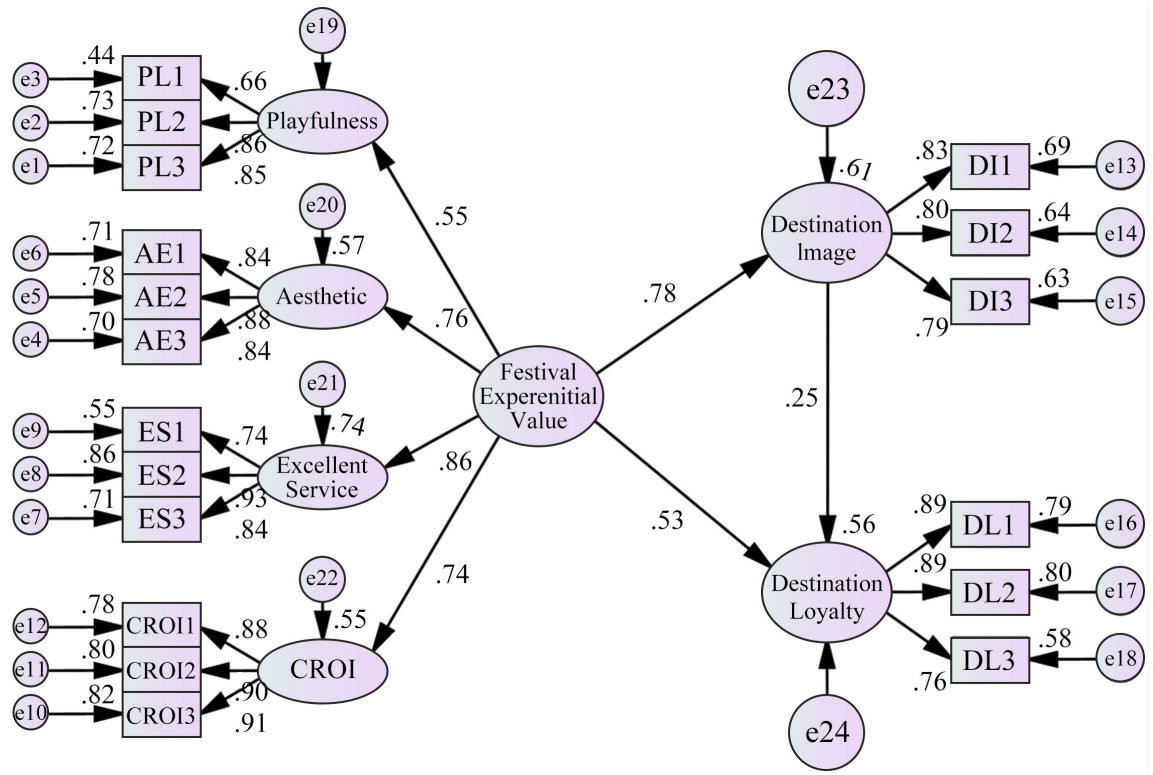

Figure 3. Results of structural model.

Table 1. Demographic Characteristics of participants $(\mathrm{N}=374)$.

\begin{tabular}{ccc}
\hline Variables & Categories & Frequency (\%) \\
\hline Gender & Male & $40.9 \%$ \\
& Female & $59.1 \%$ \\
\hline Age & $18-29$ & $64.7 \%$ \\
& $30-39$ & $22.0 \%$ \\
\hline Times visit Macau & $40-49$ & $10.2 \%$ \\
& $\geq 50$ & $3.20 \%$ \\
\hline Partnership & First & $61.5 \%$ \\
& Second & $17.6 \%$ \\
& Third or more & $20.9 \%$ \\
\hline & Independently & $9.40 \%$ \\
& With family & $54.0 \%$ \\
& With friends & $24.8 \%$
\end{tabular}

Table 2. Results of CFA of LVs $(\mathrm{N}=374)$.

\begin{tabular}{cccc}
\hline LVs/Items & Factor loadings & $\begin{array}{c}\text { Composite } \\
\text { reliability }\end{array}$ & $\begin{array}{c}\text { Variance } \\
\text { extracted }\end{array}$ \\
\hline Playfulness & & 0.839 & 0.637 \\
PL1 & 0.67 & & \\
PL2 & 0.85 & & \\
PL3 & 0.86 & & \\
\hline
\end{tabular}




\section{Continued}

\begin{tabular}{|c|c|c|c|}
\hline Aesthetic & & 0.890 & 0.729 \\
\hline AE1 & 0.84 & & \\
\hline AE2 & 0.88 & & \\
\hline AE3 & 0.84 & & \\
\hline Service Excellent & & 0.880 & 0.712 \\
\hline ES1 & 0.74 & & \\
\hline ES2 & 0.93 & & \\
\hline ES3 & 0.85 & & \\
\hline Customer Return on Investment & & 0.925 & 0.824 \\
\hline CROI1 & 0.88 & & \\
\hline CROI2 & 0.90 & & \\
\hline CROI3 & 0.91 & & \\
\hline Destination Image & & 0.848 & 0.651 \\
\hline DI1 & 0.83 & & \\
\hline DI2 & 0.80 & & \\
\hline DI3 & 0.79 & & \\
\hline Destination Loyalty & & 0.888 & 0.727 \\
\hline DL1 & 0.89 & & \\
\hline DL2 & 0.90 & & \\
\hline DL3 & 0.76 & & \\
\hline
\end{tabular}

Table 3. Correlations (Squared Correlation) and AVE.

\begin{tabular}{ccccccc}
\hline Measures & PL & AE & ES & CROI & DI & DL \\
\hline PL & 1.000 & & & & & \\
AE & 0.144 & 1.000 & & & & \\
ES & 0.221 & 0.397 & 1.000 & & & \\
CROI & 0.123 & 0.360 & 0.449 & 1.000 & & \\
DI & 0.230 & 0.336 & 0.449 & 0.325 & 1.000 & \\
DL & 0.260 & 0.336 & 0.384 & 0.221 & 0.449 & 1.000 \\
AVE & 0.637 & 0.729 & 0.712 & 0.824 & 0.651 & 0.727 \\
\hline
\end{tabular}

Table 4. Goodness-of-fit index results for path analysis.

\begin{tabular}{cccccccccc}
\hline \multirow{2}{*}{ Model-fit Index } & \multicolumn{3}{c}{ Absolute fit index } & \multicolumn{3}{c}{ Comparative fit index } & \multicolumn{3}{c}{ Parsimony fit index } \\
\cline { 2 - 9 } & $\mathrm{x}^{2} / \mathrm{df}$ & GFI & RMSEA & CFI & TLI & NFI & PGFI & PNFI & PCFI \\
\hline $\begin{array}{c}\text { Recommended } \\
\text { Level }\end{array}$ & $1-3$ & $>0.8$ & $<0.08$ & $>0.9$ & $>0.9$ & $>0.9$ & $>0.5$ & $>0.5$ & $>0.5$ \\
CFA Indicators & 2.873 & 0.903 & 0.71 & 0.953 & 0.940 & 0.930 & 0.634 & 0.729 & 0.747 \\
PA Indicators & 2.884 & 0.897 & 0.71 & 0.949 & 0.939 & 0.925 & 0.672 & 0.774 & 0.794 \\
\hline
\end{tabular}


Table 5. Results of hypothesis testing.

\begin{tabular}{cccccc}
\hline Hypothesis & $\beta$ & S.E. & C.R. & $P$ & Judgment \\
\hline EV $\rightarrow$ DI & 0.469 & 0.034 & 13.713 & $* * *$ & Support \\
EV $\rightarrow$ DL & 0.253 & 0.092 & 2.759 & $0.006^{* *}$ & Support \\
DI $\rightarrow$ DL & 0.323 & 0.056 & 5.729 & $* * *$ & Support \\
\hline
\end{tabular}

${ }^{* * *} P<0.001,{ }^{* *} P<0.01,{ }^{*} P<0.05$.

\section{Conclusion}

According to empirical research in this study, destination image and loyalty are positively influenced by experiential value in food festival, while destination image influent destination loyalty positively. These conclusions are consistent with the findings of Folgado-Fernández, Hernández-Mogollón and Duarte (2016), which indicated that food experience in gastronomic activities has a positive impact on destination image and contributes to destination loyalty.

The importance of experiential value in food festival is verified by examining the relationship among experiential value and destination image and destination loyalty. Playfulness can be improved by increasing the entertainment in festivals, such as enriching delicious foods or adding recreational areas. Aesthetics originates from the design of festivals. The color matching of food in food festivals and even the overall environment of the festival is worth the attention of managers. Previous research proves that service quality affects experience value and loyalty of consumers (Bolton \& Drew, 1991). The service of the festival is an important way for tourists to increase the knowledge of destination humanities. The services in the food festival need to be valued by the organizers, and it's necessary to improve the quality of service by training. It is also possible to enhance the experience by improving the facilities of the festival venue. CROI is the only one of the four dimensions that relate to the property expenditure of tourists. Its impact on experience and destination image has been proved by many studies (Grewal, Monroe, \& Krishnan, 1996; Masiero \& Nicolau, 2012). Specifically, in the empirical study of Tsai and Wang (2017), CROI is the only dimension of experiential value that significantly enhances place food image.

The findings of this study enrich the knowledge of destination food festivals and provide more evidence for festival to improve the destination image and loyalty. In addition to theoretical contributions, this study also provides practical implications. In particular, experiential value was used as a measurement of food festival in this study. These results can be served as a strategic tool for formulating tourism policies, and identify the areas where food festivals need to be improved in order to enhance destination image and loyalty. Food festival is a useful tool for destination branding by establishing a unique identity. Different from the traditional advertising such as TV and Newspaper, the event of festival attracted specific customer segment. So as for government and festival organizers, four dimensions (e.g. playfulness, aesthetic, excellence service and customer return on investment) of experiential value could be considered to improve the 
destination image and enhance the loyalty of tourists to food festival. The higher of the experience, the good image of the destination may be formed, and the customer may revisit the festival and recommend to other visitors. Event planners should put forward promotional strategies that match with tourists' desire for playful and aesthetic food available in the event, as well as means to improve customer return on investment. Moreover, the model proposed in this study can be used as an applicable analysis model to evaluate the destination festival activities.

\section{Limitation and Future Research}

Although this study provides valuable references and suggestions for decision makers, there are still some limitations. One limitation is that the four dimensions of experiential value, playfulness, aesthetic, excellence service and CROI, are considered as a whole in the relationship study. Tsai and Wang (2017) explored the relationship between the four dimensions of experiential value and place food image, found that only CROI has a significant impact on place food image. Therefore, the relationship between the four dimensions, destination image and destination loyalty may be different. This can be supplemented by future research. This study found that the experiential value of food festival has a positive and significant impact on destination image and destination loyalty.

Another limitation is the particularity of the festival theme in this research, which leads to the conclusion and suggestions that narrow the applicability. Food Festival has its own particularity, which is different from other festival activities. In the future, the findings of this study can be validated in other types of festival activities to improve the applicability of the findings.

Future research can explore the relationship between experiential value and destination branding, whether the experiential value in festival will affect other types of destination brand equity besides destination image and destination loyalty.

\section{Acknowledgements}

The project "Research on hotel Customer Experience based on the concept of quality life" was funded by 10 hotels, including Park Hyatt Guangzhou, Grand Hyatt Guangzhou and Regal Hotel Group Guangdong.

\section{Conflicts of Interest}

The authors declare no conflicts of interest regarding the publication of this paper.

\section{References}

Babin, B. J., Darden, W. R., \& Griffin, M. (1994). Work and/or Fun: Measuring Hedonic and Utilitarian Shopping Value. Journal of Consumer Research, 20, 644-656. https://doi.org/10.1086/209376

Backman, S. J., \& Crompton, J. L. (1991). Differentiating between High, Spurious, Latent, 
and Low Loyalty Participants in Two Leisure Activities. Journal of Park and Recreation Administration, 9, 1-17.

Bigne, J. E., Sanchez, M. I., \& Sanchez, J. (2001). Tourism Image, Evaluation Variables and after Purchase Behaviour: Inter-Relationship. Tourism Management, 22, 607-616. https://doi.org/10.1016/S0261-5177(01)00035-8

Bolton, R. N., \& Drew, J. H. (1991). A Multistage Model of Customers' Assessments of Service Quality and Value. Journal of Consumer Research, 17, 375-384. https://doi.org/10.1086/208564

Boyne, S., Williams, F., \& Hall, D. (2002). The Isle of Arran Taste Trail. In A.-M. Hjalager, \& G. Richards (Eds.), Tourism and Gastronomy (pp. 91-114). London: Routledge.

Chalip, L., \& Costa, C. (2005). Sport Event Tourism and the Destination Brand: Towards a General Theory. Sport in Society, 8, 218-237. https://doi.org/10.1080/17430430500108579

Chi, C. G., \& Qu, H. (2008). Examining the Structural Relationships of Destination Image, Tourist Satisfaction and Destination Loyalty: An Integrated Approach. Tourism Management, 29, 624-636. https://doi.org/10.1016/j.tourman.2007.06.007

Crompton, J. (1979). Motivations for Pleasure Vacation. Annals of Tourism Research, 6, 408-424. https://doi.org/10.1016/0160-7383(79)90004-5

Deng, Q., \& Li, M. (2014). A Model of Event-Destination Image Transfer. Journal of Travel Research, 53, 69-82. https://doi.org/10.1177/0047287513491331

Deng, Y. T., \& Lee, H. (2019). Exploring the Dimensions of Bed and Breakfast (B\&B) Visitors' Experiences. International Journal of Tourism Sciences, 19, 166-180. https://doi.org/10.1080/15980634.2019.1663989

DeVellis, R. F. (2003). Scale Development (2nd ed.). Thousand Oaks, CA: Sage Publications.

Dodds, W. B., \& Monroe, K. B. (1985). The Effect of Brand and Price Information on Subjective Product Evaluations. Advances in Consumer Research, 12, 87-90.

Fakeye, P. C., \& Crompton, J. L. (1991). Image Differences between Prospective, First Time, and Repeat Visitors to the Lower Rio Grande Valley. Journal of Travel Research, 30, 10-16. https://doi.org/10.1177/004728759103000202

Folgado-Fernández, J. A., Hernández-Mogollón, J. M., \& Duarte, P. (2016). Destination Image and Loyalty Development: The Impact of Tourists' Food Experiences at Gastronomic Events. Scandinavian Journal of Hospitality and Tourism, 17, 92-110. https://doi.org/10.1080/15022250.2016.1221181

Fornell, C., \& Larcker, D. F. (1981). Evaluating Structural Equation Models with Unobservable Variables and Measurement Error. Journal of Marketing Research, 18, 39-50. https://doi.org/10.1177/002224378101800104

Fox, R. (2007). Reinventing the Gastronomic Identity of Croatian Tourist Destinations. International Journal of Hospitality Management, 26, 546-559. https://doi.org/10.1016/j.ijhm.2006.03.001

Funk, D. C., Mahony, D. F., Nakazawa, M., \& Hirakawa, S. (2001). Development of the Sport Interest Inventory (SII): Implications for Measuring Unique Consumer Motives at Sporting Events. International Journal of Sports Marketing \& Sponsorship, 3, 291-316. https://doi.org/10.1108/IJSMS-03-03-2001-B005

Grewal, D., Monroe, K. B., \& Krishnan, R. (1996). The Effects of Price-Comparison Advertising on Buyers' Perceptions of Acquisition Value and Transaction Value. Cambridge, MA: Marketing Science Institute, Report No. 96-103.

Hair, J. F. J., Black, W. C., Babin, B. J., \& Anderson, R. E. (2014). Multivariate Data Anal- 
ysis (7th ed.). Harlow: Pearson.

Hall, M., \& Mitchell, R. (2001). Wine and Food Tourism. In N. Douglas, \& R. Derrett (Eds.), Special Interest Tourism (pp. 307-325). Sydney: Wiley.

Hammitt, W. E., Backlund, E. A., \& Bixler, R. D. (2006). Place Bonding for Recreation Places: Conceptual and Empirical Development. Leisure Studies, 25, 17-41. https://doi.org/10.1080/02614360500098100

Holbrook, M. B. (1986). Emotion in the Consumption Experience: Toward a New Model of the Human Consumer. In The Role of Affect in Consumer Behavior: Emerging Theories and Applications (pp. 17-52). Lexington, MA: D.C. Heath.

Holbrook, M. B. (1994). The Nature of Customer Value: An Axiology of Services in the Consumption Experience. In R. T. Rust, \& R. L. Oliver (Eds.), Service Quality: New Directions in Theory and Practice (pp. 21-71). Newbury Park, CA: Sage. https://doi.org/10.4135/9781452229102.n2

Horng, J.-S., \& Tsai, C.-T. (2012). Constructing Indicators of Culinary Tourism Strategy: An Application of Resource-Based Theory. Journal of Travel Tourism Marketing, 29, 796-816. https://doi.org/10.1080/10548408.2012.730945

Hsu, F. C., \& Scott, N. (2020). Food Experience, Place Attachment, Destination Image and the Role of Food-Related Personality Traits. Journal of Hospitality and Tourism Management, 44, 79-87. https://doi.org/10.1016/j.jhtm.2020.05.010

Ignatov, E., \& Smith, S. (2006). Segmenting Canadian Culinary Tourists. Current Issues in Tourism, 9, 235-255. https://doi.org/10.2167/cit/229.0

Jang, S. C., \& Feng, R. (2007). Temporal Destination Revisit Intention: The Effects of Novelty Seeking and Satisfaction. Tourism Management, 28, 580-590. https://doi.org/10.1016/j.tourman.2006.04.024

Jang, S. S., \& Namkung, Y. (2009). Perceived Quality, Emotions, and Behavioral Intentions: Application of an Extended Mehrabian-Russell Model to Restaurants. Journal of Business Research, 62, 451-460. https://doi.org/10.1016/j.jbusres.2008.01.038

Kim, J., Kang, J. H., \& Kim, Y. K. (2014). Impact of Mega Sport Events on Destination Image and Country Image. Sport Marketing Quarterly, 23, 161-175.

Kim, N.-S., \& Chalip, L. (2004). Why Travel to the FIFA World Cup? Effects of Motives, Background, Interest, and Constraints. Tourism Management, 25, 695-707. https://doi.org/10.1016/j.tourman.2003.08.011

Kivela, J. (2006). Tourism and Gastronomy: Gastronomy's Influence on How Tourists Experience a Destination. Journal of Hospitality \& Tourism Research, 30, 354-377. https://doi.org/10.1177/1096348006286797

Kolb, B. (2006). Tourism Marketing for Cities and Towns: Using Branding and Events to Attract Tourists. Amsterdam: Elsevier Butterworth-Heinemann. https://doi.org/10.4324/9780080460758

LaSalle, D., \& Britton, T. A. (2003). Priceless: Turning Ordinary Products into Extraordinary Experiences. Brighton, MA: Harvard Business School Press.

Lee, I., \& Arcodia, C. (2011). The Role of Regional Food Festivals for Destination Branding. International Journal of Tourism Research, 13, 355-367.

https://doi.org/10.1002/jtr.852

Lee, Y.-K., Lee, C.-K., Lee, S.-K., \& Babin, B. J. (2008). Festival Scapes and Patrons' Emotions, Satisfaction, and Loyalty. Journal of Business Research, 61, 56-64. https://doi.org/10.1016/j.jbusres.2006.05.009

Masiero, L., \& Nicolau, J. L. (2012). Tourism Market Segmentation Based on Price Sensitivity: Finding Similar Price Preferences on Tourism Activities. Journal of Travel Re- 
search, 51, 426-435. https://doi.org/10.1177/0047287511426339

Mathwick, C., Malhotra, N., \& Rigdon, E. (2001). Experiential Value: Conceptualization, Measurement and Application in the Catalog and Internet Shopping Environment. Journal of Retailing, 77, 39-56. https://doi.org/10.1016/S0022-4359(00)00045-2

Norris, R. T. (1941). The Theory of Consumer's Demand. New Haven, CT: Yale University Press.

Okumus, F., Kock, G., Scantlebury, M. M. G., \& Okumus, B. (2013). Using Local Cuisines When Promoting Small Caribbean Island Destinations. Journal of Travel Tourism Marketing, 30, 410-429. https://doi.org/10.1080/10548408.2013.784161

Oppermann, M. (2000). Tourism Destination Loyalty. Journal of Travel Research, 39, 78-84. https://doi.org/10.1177/004728750003900110

Parasuraman, A., Zeithaml, V. A., \& Berry, L. L. (1998). SERVQAL: A Multiple-Item Scale for Measuring Consumer Perceptions of Service. Journal of Retailing, 64, 12-40.

Pine, B. J., \& Gilmore, J. H. (1998). Welcome to the Experience Economy. Harvard Business Review, 76, 97-105.

Qu, H., Kim, L. H., \& Im, H. H. (2011). A Model of Destination Branding: Integrating the Concepts of the Branding and Destination Image. Tourism Management, 32, 465-476.

https://doi.org/10.1016/j.tourman.2010.03.014

Quan, S., \& Wang, N. (2004). Towards a Structural Model of the Tourist Experience: An Illustration from Food Experiences in Tourism. Tourism Management 25, 297-305. https://doi.org/10.1016/S0261-5177(03)00130-4

Ragb, H., Mahrous, A. A., \& Ghoneim, A. (2020). A Proposed Measurement Scale for Mixed-Images Destinations and Its Interrelationships with Destination Loyalty and Travel Experience. Tourism Management Perspectives, 35, Article ID: 100677. https://doi.org/10.1016/j.tmp.2020.100677

Rand, G., Heath, E., \& Alberts, N. (2003). The Role of Local and Regional Food in Destination Marketing: A South African Situation Analysis. Journal of Travel and Tourism Marketing, 14, 97-112. https://doi.org/10.1300/J073v14n03 06

Ryu, K., \& Han, H. (2011). New or Repeat Customers: How Does Physical Environment Influence Their Restaurant Experience? International Journal of Hospitality Management, 30, 599-611. https://doi.org/10.1016/j.ijhm.2010.11.004

Sims, R. (2009). Food, Place and Authenticity: Local Food and the Sustainable Tourism Experience. Journal of Sustainable Tourism, 17, 321-336.

https://doi.org/10.1080/09669580802359293

Sørensen, F., \& Jensen, J. F. (2015). Value Creation and Knowledge Development in Tourism Experience Encounters. Tourism Management, 46, 336-346. https://doi.org/10.1016/j.tourman.2014.07.009

Stone, M., Soulard, J., Migacz, S., \& Wolf, E. (2018). Elements of Memorable Food, Drink, and Culinary Tourism Experience. Journal of Travel Research, 57, 1121-1132. https://doi.org/10.1177/0047287517729758

Telfer, D., \& Wall, G. (1996). Linkages between Tourism and Food Production. Annals of Tourism Research, 23, 635-653. https://doi.org/10.1016/0160-7383(95)00087-9

Tsai, C.-T., \& Wang, Y.-C. (2017). Experiential Value in Branding Food Tourism. Journal of Destination Marketing \& Management, 6, 56-65. https://doi.org/10.1016/j.jdmm.2016.02.003

Xu, Y. H., Wong, I. A., \& Tan, X. S. (2016). Exploring Event Bundling: The Strategy and Its Impacts. Tourism Management, 52, 455-467.

https://doi.org/10.1016/j.tourman.2015.07.014 
Yvette, R., \& Turner, L. W. (2002). Cultural Differences between Asian Markets and Australian Hosts, Part I. Journal of Travel Research, 40, 295-315.

https://doi.org/10.1177/0047287502040003008

Zeithaml, V. A. (1988). Customer Perceptions of Price, Quality, and Value: A Means-End Model and Synthesis of Evidence. Journal of Marketing, 52, 2-22. https://doi.org/10.1177/002224298805200302

Zhang, H., Fu, X., Cai, L. A., \& Lu, L. (2014). Destination Image and Tourist Loyalty: A Meta-Analysis. Tourism Management, 40, 213-223.

https://doi.org/10.1016/j.tourman.2013.06.006 